\title{
HUBUNGAN PATOFISIOLOGI HIPERTENSI DAN HIPERTENSI RENAL
}

\author{
Akmarawita Kadir \\ Bagian Ilmu Faal Fakultas Kedokteran Universitas Wijaya Kusuma Surabaya \\ Email : akmarawita@gmail.com
}

\begin{abstract}
Abstrak
Latar Belakang : Hipertensi merupakan penyakit dengan tingkat kejadian yang masih tinggi di seluruh dunia, sebagian besar penyebab hipertensi tidak diketahui (hipertensi esensial / hipertensi primer), sebagian kecil hipertensi disebabkan oleh penyakit yang didapat (hipertensi sekunder). Hipertensi yang tidak diketahui penyebabnya menyebabkan komplikasi berbagai penyakit yang memperparah penyakit tersebut misalnya penyakit ginjal (renal disease), dan dapat menjadi penyakit yang malah menyebabkan hipertensi menjadi lebih berat (hipertensi sekunder). Patofisiologi kejadian hipertensi esensial sudah banyak di kemukakan karena kasusnya banyak terjadi, tetapi patofisiologi penyakit ginjal (renal disease) yang menyebabkan hipertensi masih perlu didalami kembali, terutama mengenai hubungan antara hipertensi primer dan hipertensi sekunder (hipertensi ginjal atau renal hypertention). Penyakit Ginjal (renal disease) merupakan penyakit yang dapat menimbulkan hipertensi melalui mekanisme peningkatan resistensi peredaran darah ke ginjal dan penurunan fungsi kapiler glomerulus. Penurunan fungsi kapiler glomerulus mengakibatkan keluarnya substansi-subtansi yang penting seperti renin, angiotensinogen, angiotensin I, angiotensin II, angiotensin converting enzim (ACE), aldosteron, bradikinin, nitric oxide (NO) yang pada akhirnya menyebabkan meningkatnya tekanan darah (hipertensi). Sedangkan Hipertensi ternyata merupakan mekanisme umpan balik untuk menekan tingginya renin, tetapi penekanan renin ini tidak akan berarti apabila penyakit ginjal tidak diobati dengan baik, dan bahkan menyebabkan hipertensi menjadi menetap atau bertambah berat. Tujuan penulisan untuk mengetahui patofisiolgi hipertensi, khususnya hipertensi renal, dan bagaimana hubungan antara hipertensi dengan hipertensi ginjal (sekunder).
\end{abstract}

Kata Kunci : Patofisiolgi, Hipetensi, Hipertensi renal, Renin, Agiotensin, ACE

\section{THE PATHOPHYSIOLOGY RELATIONSHIP OF HYPERTENSION AND RENAL HYPERTENSION}

\begin{abstract}
Introduction : Hypertension is a disease with an incidence rate is still high around the world, most of the causes of hypertension is unknown (essential hypertension / primary hypertension), a small portion of hypertension caused by diseases acquired (secondary hypertension). The unknown cause of Hypertension causing complications of diseases that worsen it, eg kidney disease (renal disease), and can be a disease that actually cause hypertension becomes more severe (secondary hypertension). Pathophysiology of essential
\end{abstract}


hypertension has been a lot of discussed, but the pathophysiology of renal disease which causes hypertension still needs to be explored, particularly on the relationship between primary hypertension and secondary hypertension (hypertension, kidney or renal hypertention).

Kidney disease is a disease that cause hypertension via the mechanism of resistance increases blood circulation to the kidneys and a decrease in the glomerular capillary function which resulted in the release of an important substance-substance such as renin, angiotensinogen, angiotensin I, angiotensin II, angiotensin converting enzyme (ACE) inhibitors, aldosterone, bradykinin, nitric oxide (NO), which in turn causes increase blood pressure (hypertension). Hypertension proved to be a feedback mechanism to suppress the high renin, renin suppression doesn't mean anything if kidney disease not treated properly, and even cause permanently hypertension or even getting worse. The purpose of this article was to determine the pathophysiology of hypertension, renal hypertension in particular, and how the relationship between hypertension and renal hypertension (secondary).

Keywords : Pathophysiology, hypertension, renal hypertension, renin, angiotensin, ACE

\section{PENDAHULUAN}

Hipertensi merupakan penyakit yang sampai sekarang banyak ditemukan di dunia, bahkan sampai sekarang kasus hipertensi terus meningkat seiring kemajuan zaman, yaitu dengan peningkatan perubahan pola hidup yang tidak sehat. Dahulu hipertensi banyak di temukan pada kasus-kasus usia lanjut, tetapi sekarang hipertensi sudah mulai banyak di temukan pada usia muda ${ }^{1,2,3}$.

Penyebab Hipertensi sudah banyak di perbincangkan, dan yang paling sering di bahas adalah dua penyebab hipertensi yaitu hipertensi primer dan hipertensi sekunder. Hipertensi primer mendominasi penyebab hipertensi yaitu $95 \%$ hipertensi adalah hipertensi primer yang disebut juga hipertensi esensial, dan sisanya 5\% adalah hipertensi sekunder. Salah satu penyebab terjadinya hipertensi sekunder adalah penyakit ginjal yang biasa dikenal dengan hipertensi renal $^{4,2}$.

Terjadinya Hipertensi Renal masih perlu dibahas lebih dalam, tujuan penulisan artikel ini adalah untuk mengetahui bagaimana ginjal dapat menyebabkan hipertensi, dan apakah hipertensi juga dapat menyebabkan penyakit ginjal, serta hubungan keduanya.

\section{TINJAUAN PUSTAKA \\ DEFINISI HIPERTENSI}

Hipertensi adalah meningkatnya tekanan sistolik dan tekanan diastolik pada seorang diatas nilai yang telah ditentukan seperti pada Gambar. $1^{5}$. 


\begin{tabular}{|l|l|l|l|}
\hline $\begin{array}{l}\text { Blood Pressure } \\
\text { Category }\end{array}$ & $\begin{array}{l}\text { Systolic } \\
\text { mm Hg (Upper }\end{array}$ & & $\begin{array}{l}\text { Diastolic } \\
\mathbf{m m ~ H g} \text { (Lower }\end{array}$ \\
\hline Normal & Less than 120 & And & Less than 80 \\
\hline Prehypertension & $120-139$ & Or & $80-89$ \\
\hline $\begin{array}{l}\text { High Blood Pressure } \\
\text { (Hypertension) Stage 1 }\end{array}$ & $140-159$ & Or & $90-99$ \\
\hline $\begin{array}{l}\text { High Blood Pressure } \\
\text { (Hypertension) Stage 2 }\end{array}$ & 160 or higher & Or & 100 or higher \\
\hline $\begin{array}{l}\text { Hypertensive Crisis } \\
\text { (Emergency care } \\
\text { needed) }\end{array}$ & Higher than 180 & Or & Higher than 110 \\
\hline
\end{tabular}

Gambar 1. Kriteria Hipertensi ${ }^{5}$.

Tekanan darah sistolik adalah tekanan darah pada saat jantung memompa darah ke seluruh tubuh (fase ejeksi) yang biasanya di tulis pada nilai atas. Sedangkan tekanan darah diastolik adalah tekanan darah pada saat jantung istirahat (dalam hal ini ventrikel diisi oleh sejumlah darah dari atrium) ${ }^{6}$.

\section{TERJADINYA HIPERTENSI}

Banyak faktor yang menyebabkan seseorang mengalami peningkatan tekanan sistole dan atau diastole, tetapi sebenarnya peningkatan ini terjadi akibat 2 parameter yang meningkat yaitu peningkatan tahanan perifer total tubuh dan peningkatan cardiac output / curah jantung (Gambar 2). Sehingga dapat dikatakan bahwa segala sesuatu yang menyebabkan terjadinya peningkatan salah satu atau keduanya, maka akan menyebabkan orang tersebut mengalami peningkatan tekanan darah (hipertensi) ${ }^{4,7}$.

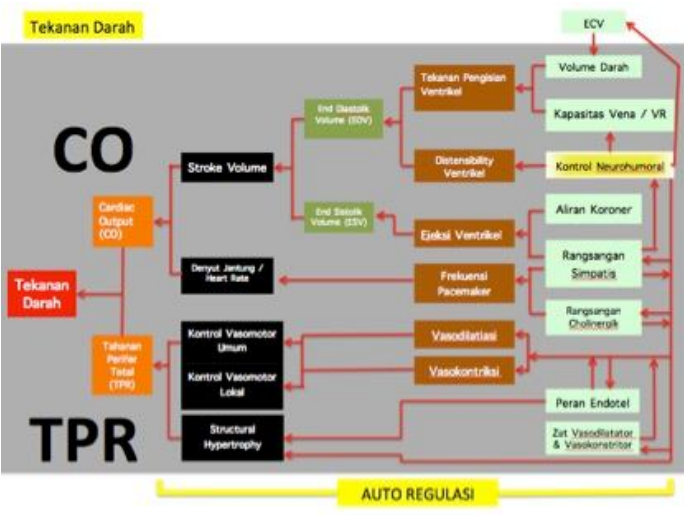

Gambar 2. Skema Hipertensi. Dua Parameter penting yang menyebabkan perubahan tekanan darah yaitu tahanan perifer total (TPR) dan curah jantung / cardiac output $(\mathrm{CO})^{7}$.

\section{PENYAKIT GINJAL MENYEBAB-}

\section{KAN HIPERTENSI}

Ginjal merupakan salah satu organ bagi tubuh manusia yang berfungsi penting dalam homestasis yaitu mengeluarkan sisasisa metabolisme, menjaga keseimbangan cairan dan elektrolit, memproduksi hormon yang dapat mempengaruhi organorgan lainnya, salah satu contohnya adalah kontrol tekanan darah dalam menyeimbangkan tekanan darah. Organ ginjal itu sendiri bekerja di dukung oleh aliran darah ke ginjal, jaringan ginjal dan saluran pembungan ginjal, bila salah satu faktor pendukung terganggu maka akan menyebabkan fungsi ginjal akan terganggu bahkan dapat berhenti ${ }^{6,8}$. 
Beberapa penyakit ginjal yang menyebabkan hipertensi yaitu : a. renovascular : renal artery steonosis, polyarteritis nodusa, renal artery neurysm, renal artery malformation; b. Renoparenchymal : glomerulonephritis, polycystic kidney disease, analgesic nephropathy, renal tumor as Wilms' tumor, dan penyakit parenchmal lainnya. Penyakit-penyakit ini pada intinya dapat menyebabkan dua kejadian penting yaitu 1) peningkatan resistensi peredaran darah ke ginjal; dan 2) penurunan fungsi kapiler glomerulus. Hal ini menyebabkan terjadinya ischemia pada ginjal yang merangsang peningkatan pengeluaran renin (pro renin menjadi renin) pada glomerular sel. (Gambar 3).

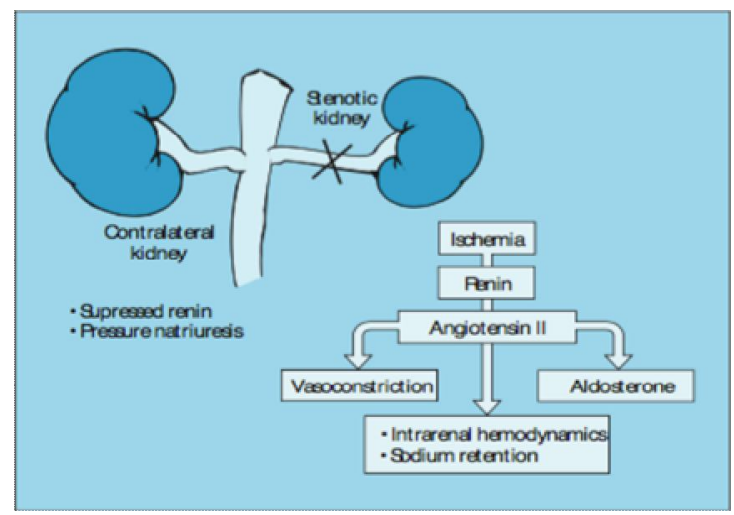

Gambar 3. Skema hipertensi renovaskuler. Iskemia merangsang pengeluaran renin dan menyebabkan terbentuknya Angiotensin II yang mengakibatkan intrarenal hemodynamics dan sodium retention ${ }^{8}$.

Renin ini akan menyebabkan meningkatnya angiotensin I dan angiotensin II yang mempunyai efek vasokontrisi dan pengeluaran aldosteron yang mempunyai efek intrarenal hemodynamics dan sodium retention (presure natriuresis).

Iskemia ginjal merupakan faktor utama penyebab terjadinya hipertensi, iskemia yang merupakan kurangnya pasokan darah menuju ginjal karena berbagai penyakit pada ginjal, menyebabkan pengurangan tekanan arteri sistemik proksimal ke lesi (distal), sehingga menginduksi hipo-perfusi untuk segmen arteri distal, hal ini menyebabkan mekanisme autoregulation yang sebenarnya untuk memulihkan hipoperfusi pada ginjal. Kejadian ini akan merangsang terbentuknya hormon enzimatik yaitu renin (dikeluarkan oleh sel granular aparatus jukstraglomerulus). Renin yang telah diproduksi akan dibawa oleh darah yang dapat berikatan dengan angiotensinogen menjadi angitensin I, angiotensin I yang terbentuk dapat dirubah menjadi angiotensin II oleh ACE (angiotensin converting enzim) yang diproduksi di jaringan paru maupun di sel endotel pembuluh darah. Angiotensin II dapat mengaktifkan AT1 Reseptor akibatnya akan terjadi efek vasokontriksi yang kuat pada pembuluh darah, rangsangan aldosteron yang menyebabkan retensi $\mathrm{Na}$ dan Air, meningkatnya inflamasi, meningkatnya oksidatif stres yang menurnkan kadar NO, dan meningkatnya fibrosis.(Gambar 4 dan 5). 
Angiotensin converting enzim yang ada dalam darah juga mempunyai efek menurunkan bradikinin dan Nitric Oxide (NO) yang menambah terjadinya efek Vasokonstriksi (Gambar 6). Angiotensin II juga tidak hanya dihasilkan oleh renin, tetapi juga oleh non renin yaitu dapat diproduksi langsung oleh angiotensinogen dan angiotensin I tanpa ACE (melalui enzim chymase) (Gambar 5).

\section{Rangsangan Aldosteron oleh} angiotensin II akan menyebabkan retensi natrium dan air. Angiotensin II juga mempunyai efek meningkatkan risiko terjadinya atherosclerosis akibat meningkatnya inflamasi. Sehingga pada akhirnya efek keseluruhan akan menyebabkan meningkatnya tekanan darah atau hipertensi, bahkan bila tidak diobati akan menyebabkan hipertensi yang menetap (Gambar 7) 2,9,8,10.

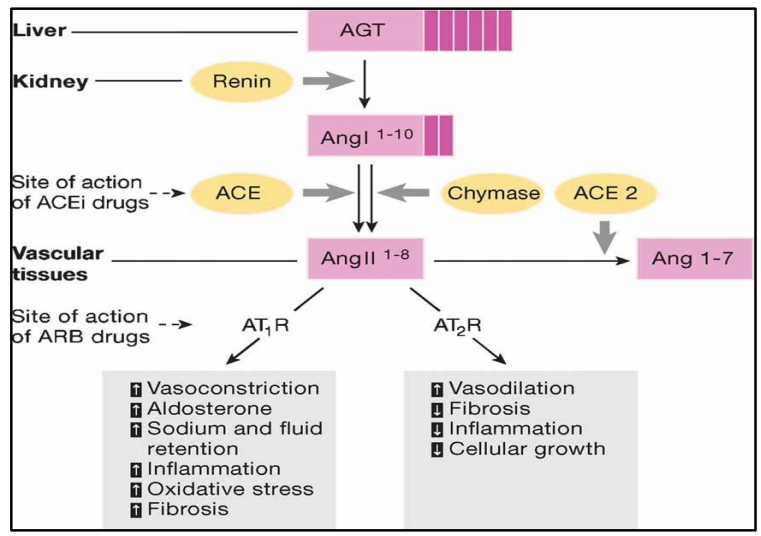

Gambar 4. Efek Angiotensin II. Efek terhadap AT1 $\mathrm{R}$ akibat rangsangan Renin adalah Meningkatnya vasokontriksi, keluarnya aldosterone, retensi air dan $\mathrm{Na}$, Meningkatnya inflamasi, oksidatif stress dan meningkatnya fibrosis ${ }^{11}$.

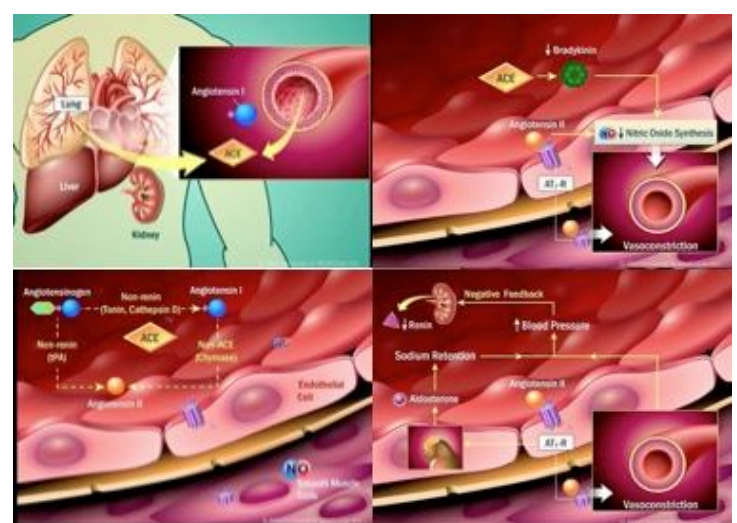

Gambar 5. The Renin - Angiotensin System. Renin yang terbentuk dari ginjal menjadi angiotensin I dan angiotensin II 12 .

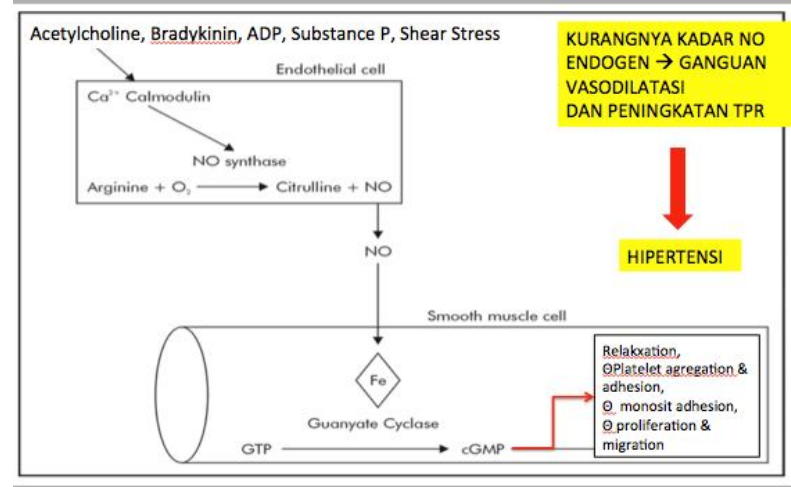

Gambar 6. Pembentukan Nitric Oxide. Hambatan NO menyebabkan Terjadinya Vasokonstriksi yang menyebabkan TPR meningkat, dan dapat minumbulkan hipertensi ${ }^{7,13}$. 


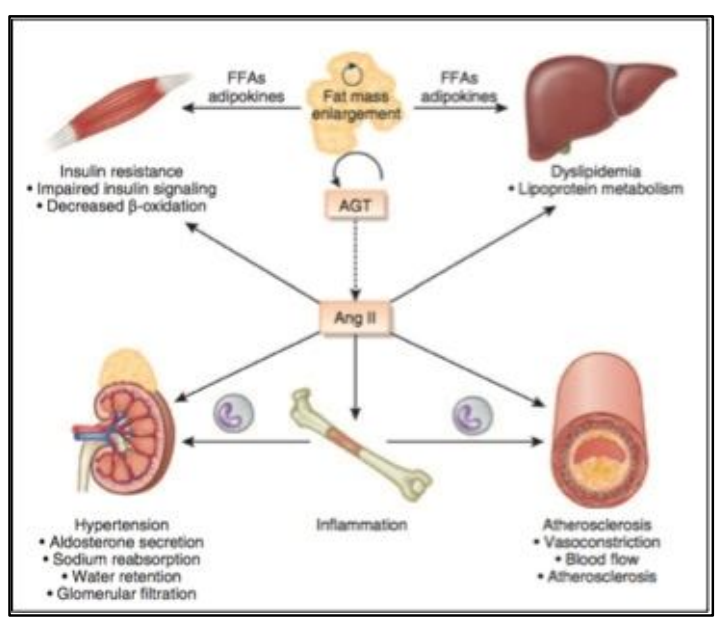

Gambar 7. Pengaruh Angiotensin II dalam patogenesis sindrom metabolik. Angiotensin II menyebabkan atherosclerosis yang merupakan factor risiko terjadinya hipertensi ${ }^{10}$.

\section{HIPERTENSI MENYEBABKAN GANGGUAN PADA GINJAL}

Penyakit hipertensi pada dasarnya adalah penyakit yang dapat merusak pembuluh darah, jika pembuluh darahnya ada pada ginjal, maka tentu saja ginjalnya mengalami kerusakan. Seseorang yang tidak mempunyai gangguan ginjal, tetapi memiliki penyakit hipertensi dan tidak diobati akan menyebabkan komplikasi pada kerusakan ginjal, dan kerusakan ginjal yang terjadi akan memperparah hipertensi tersebut. Kejadian ini menyebabkan tinkat terapi hemodialis menjadi tinggi dan angka kematian akibat penyakit ini juga cukup tinggi ${ }^{14}$.

Hipertensi menyebabkan rangsangan barotrauma pada kapiler glomerolus dan meningkatkan tekanan kapiler glomerolus terebut, yang lama kelamaan akan menyebabkan glomerolusclerosis. Glomerulusclerosis dapat merangsang terjadinya hipoksia kronis yang menyebabkan kerusakan ginjal. Hipoksia yang terjadi menyebabkan meningkatnya kebutuhan metabolisme oksigen pada tempat tersebut, yang menyebakan keluarnya substansi vasoaktif (endotelin, angiotensin dan norephineprine) pada sel endotelial pembuluh darah lokal tersebut yang menyebabkan meningkatnya vasokonstriksi. Aktivasi RAS (Renin Angiotensin Sistem) disamping menyebabkan vasokontriksi, juga menyebakan terjadinya stres oksidatif yang meningkatkan kebutuhan oksigen dan memperberat terjadinya hipoksia. Stres oksidatif juga menyebabkan penurunan efesiensi transport natrium dan kerusakan pada DNA, lipid \& protein, sehingga pada akhirnya akan menyebakan terjadinya tubulointertitial fibrosis yang memperparah terjadinya kerusakan ginjal. (Gambar 8) ${ }^{15}$. 


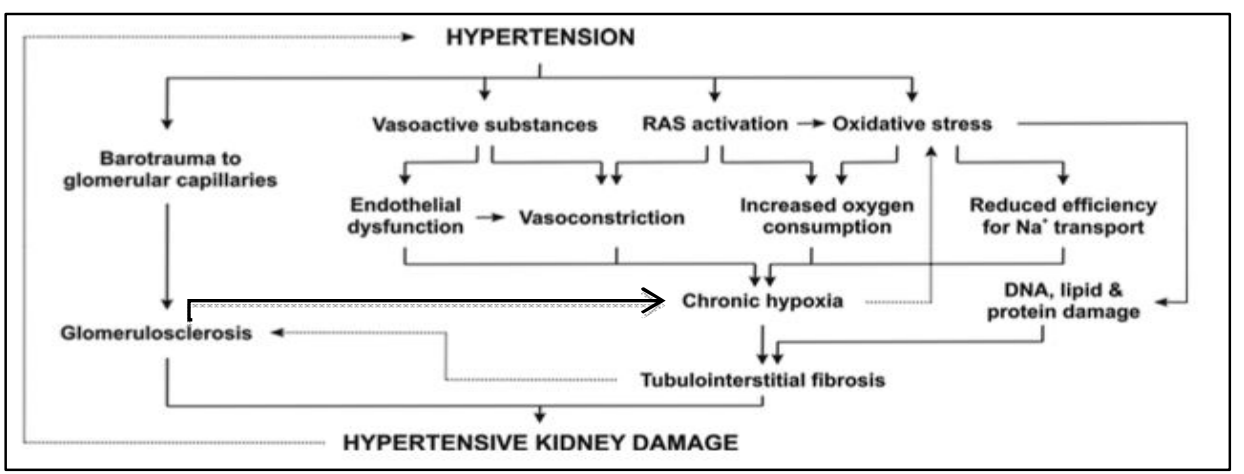

Gambar 8. Mekanisme kerusakan ginjal pada hipertensi. Hipertensi menyebabkan kerusakan sel glomerular, meningkatkan vasoaktiv substance, atkivasi RAS, dan stress oksitatif yang menyebabkan terjadinya hipoksia kronis dan menyebabkan kerusakan ginjal ${ }^{15,16}$.

\section{PEMBAHASAN}

Hipertensi renal merupakan hipertensi sekunder yang angka kejadiannya sekitar $5 \%$, jauh lebih sedikit dibanding dengan hipertensi primer. Tetapi kejadian hipertensi renal yang terjadi dapat merupakan komplikasi dari hipertensi primer. Hipertensi primer yang menetap dan tidak diobati dapat menyebabkan kerusakan ginjal dan kemudian kerusakan ginjal dapat menyebakan hipertensi menjadi lebih parah dan dapat menyebabkan komplikasi yang lainnya. Sedangkan penyakit ginjal yang didapat (Renal disease) terutama yang menyebabkan peningkatan resistensi peredaran darah ke ginjaldan penurunan fungsi kapiler glomerulus akan menyebabkan terjadinya hipertensi, dan apabila penyakit ginjal tidak diobati maka akan menyebabkan hipertensi menetap dan memperparah kerusakan ginjal. Sehingga dapat dikatakan antara hipertensi dan kerusakan ginjal adalah saling berhubungan satu sama lain. (Gambar 9)

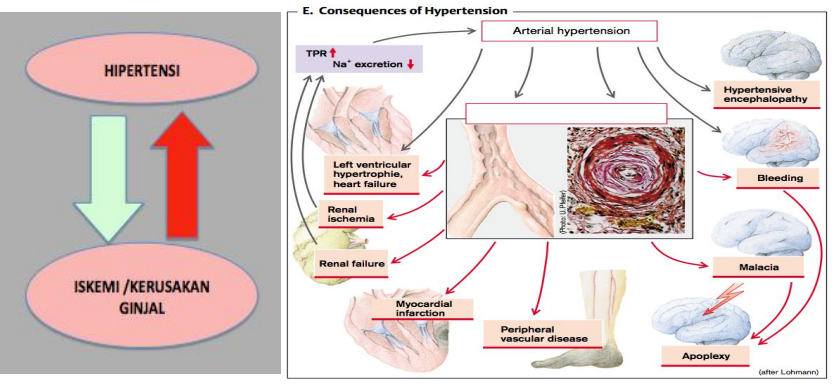

Gambar 9. Hubungan antara hipertensi dan kerusakan Ginjal.Akibat hipertensi menyebabkan terjadinya kerusakan ginjal, dan kerusakan ginjal akan meningkatkan TPR dan menurunkan Na Ekskresi yang menyebabkan terjadinya hipertensi menjadi menetap dan bertambah berat ${ }^{4}$.

Kerusakan ginjal yang terjadi akibat penyakit ginjal menyebabkan hipoksia, yang merangsang terbentuknya renin, renin yang beredar ke seluruh tubuh akan menyebabkan meningkatnya substansi - substansi seperti angiotensinogen, angiotensin I, ACE, angiotensin II, dan aldostoeron. 
Substansi-substansi ini menyebabkan perubahan-perubahan yaitu : meningkatnya resistensi dan vasokonstriksi pembuluh darah, vasokonstriksi pembuluh darah juga diperberat oleh penurunan kadar bradikinin oleh ACE yang menyebabkan penurunan kadar Nitric Oxide (NO), penurunan NO ini akan memperberat terjadinya vasokonstriksi pembuluh darah, penurunan NO juga menyebabkan retensi $\mathrm{Na}$ atau meningkatnya reabsorbsi Natrium (renal presure natriuresis). Keadaan ini akan meningkatkan tahanan perifer total dan Cardiac Output dan menyebabkan terjadinya Hipertensi (Gambar 10 dan 11) 6,17 .

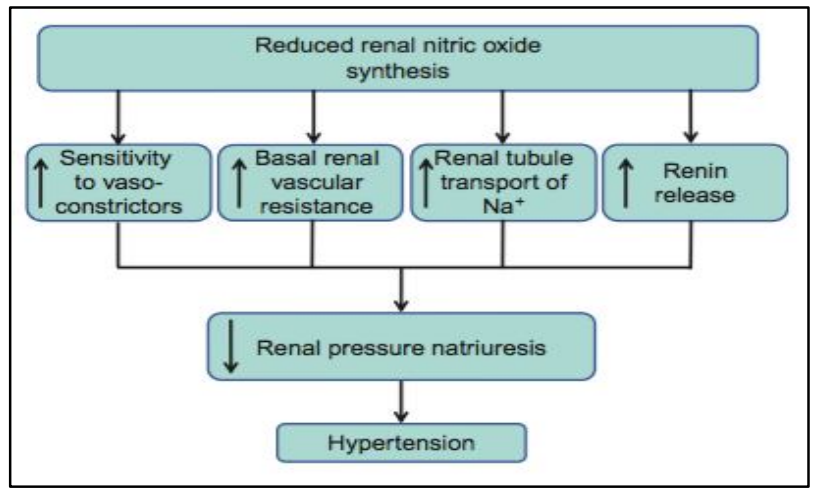

Gambar 10. Mekanisme Penurunan Nitric Oxide (NO) dan Hipertensi. Penurunan Kadar NO akan menyebabkan terjadinya pengeluaran renin, peningkatan reabsobsi $\mathrm{Na}$, peningkatan resistensi renal dan peningkatan vasokontriksi yang mengakibatkan terjadinya penurunan pengeluaran $\mathrm{Na}^{6}$.

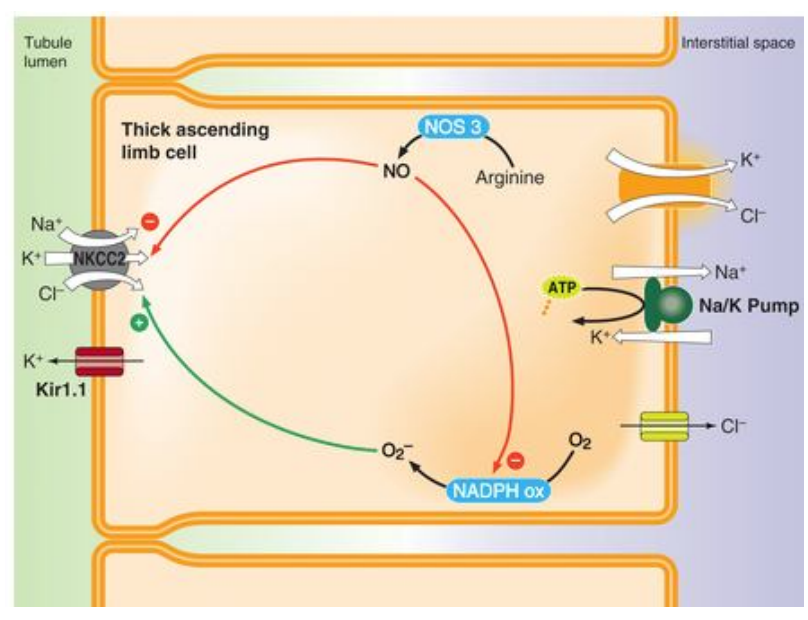

Gambar 11. Regulation of thick ascending limb $\mathrm{NaCl}$ absorption by nitric oxide (NO) Penurunan Kadar NO akan menyebabkan terjadinya hambatan pada pengeluaran Natrium ${ }^{17}$.

Angiotensin II yang terbentuk juga akan menyebabkan peningkatan vasokonstriksi pembuluh darah yang menyebabkan peningkatan tahanan perifer total, peningkatan volume plasma akibat rangsangan aldosteeron, serta peningkatan reabsorbsi NA. Peningkatan reabsorbsi $\mathrm{Na}$ ini terjadi melalui peningkatan tekanan osmotik cairan interstisial dan penurunan tekanan hidrostatik cairan interstitial. Kesemuanya ini akan memperberat terjadinya Hipertensi Gambar 11) ${ }^{6}$. 


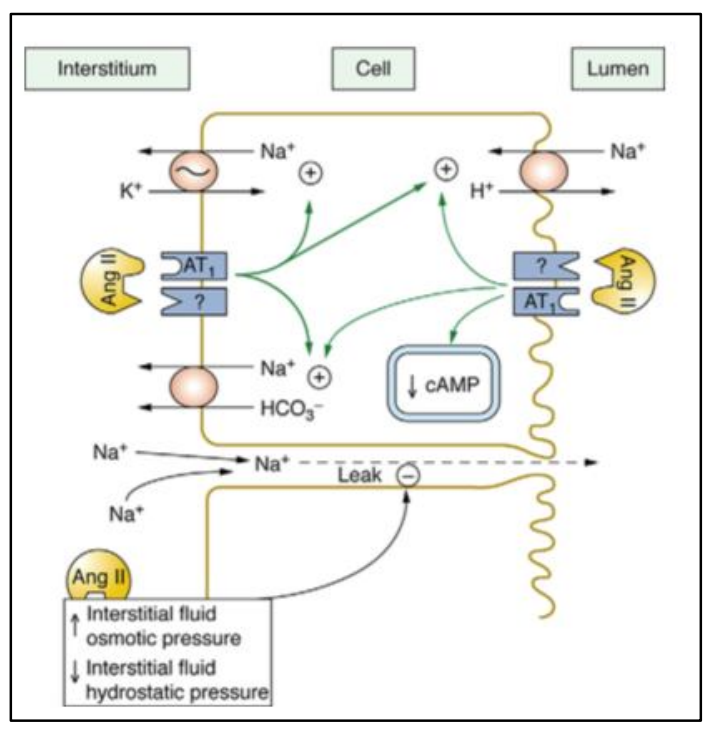

Gambar 12. Efek Angiotensin II terhadap peningkatan Reabsorbsi $\mathrm{Na}$ pada ginjal.Angiotensin II menyebabkan peningkatan tekanan osmotik cairan intertisial dan menurunkan tekanan hirostatik cairan interstisial ${ }^{6}$.

Sebenarnya peningkatan tekanan darah (hipertensi) dapat mengirimkan feedback negatif kepada ginjal untuk menurunkan produksi renin (Gambar 5), apabila kondisi ginjal baik, maka produksi renin akan di tekan dan diharapkan dapat menurunkan tekanan darah. Tapi dalam hal ini apabila kelainan terjadi pada jaringan ginjal yang rusak (renal disease), maka feedback negatif yang terjadi tidak optimal dan tidak dapat menurunkan produksi renin, kejadian ini menyebabkan terjadinya hipertensi yang menetap.

\section{KESIMPULAN}

Penyakit Ginjal (renal disease) merupakan penyakit yang dapat menimbulkan hipertensi melalui mekanisme peningkatan resistensi peredaran darah ke ginjal dan penurunan fungsi kapiler glomerulus. Mekanisme ini menimbulkan keadaan hipoksia pada ginjal dan meningkatnya aktivitas renin, angiotensinogen, angiotensin I, angiotensin II, $\mathrm{Hub}$ (ACE), aldosteron dan penurunan bradikinin, penurunan nitric oxide (NO). Peningkatan dan penurunan substansi ini menyebabkan terjadinya vasokonstriksi pembuluh darah, peningkatan tahanan perifer, serta meningkatnya volume plasma yang pada akhirnya menyebabkan peningkatan tekanan darah (hipertensi).

Hipertensi atau peningkatan tekanan darah yang terjadi akibat penyakit ginjal merupakan mekanisme umpan balik untuk menurunkan dan menyeimbangkan substansi yang keluar agar tekanan darah menjadi normal kembali, tetapi apabila kerusakan ginjal (renal disease) tidak diobati dengan baik, maka akan menambah berat penyakit hipertensi. Sehingga penanganan Hipertensi pada penyakit ginjal harus dilihat secara baik, karena keduanya saling berhubungan erat, dimana penyakit ginjal dapat menyebabkan hipertensi, dan hipertensi yang menetap dapat menyebabkan penyakti ginjal yang lebih memburuk lagi. 


\section{DAFTAR PUSTAKA}

1. Sawicka K, Szczyrk M, Jasrzebska I, Prasal M, Zowlak A, Daniluk J, 2011. Hypertention - The silent killer. Journal of Pre-Clinical and Clinical Research, 5 (2) : $43-46$

2. Sherwood L, 2013. Human physiology form cells to systems, the blood vessels and blood presure. Eight Edition. Belmont, USA : Thomson Brooks/Cole

3. Devicaesaria A, 2014. Hipertensi Krisis, Medicinus Vol 27, No. 3

4. Silbernagl S, Lang F, 2007. Color Atlat of Pathophysiology. Stuttgart, Germany: Georg Thieme Verlag.

5. American Heart Association, 2014

6. Hall JE, Granger JP, Hall ME, 2013. The Kidney. Physiology and pathophysiology of Hypertension. $5^{\text {th }}$ Ed. USA: Elsevier Inc.

7. Kadir A, 2015. Autoregulasi hipertensi, menentukan jenis hipertensi, prosiding Kongres Nasional IAIFI XVI, simposium seminar dan workshop XXIV, Padang

8. Garovic VD, Textor SC, 2005. Renovascular Hypertension and Ischemic Nephropathy, Nephrology and Hypertension, Mayo Clinic, Circulation AHA, 112:1362-1374
9. Sayedi N, Koyama M, Mackin CJ, Levi R, 2002. Ischemia Promotes Renin Activation and Angiotensin Formation in Sympathetic Nerve Terminals Isolated from the Human Heart: Contribution to CarrierMediated Norepinephrine Release. The Journal Of Pharmacology And Experimental Therapeutics, Vol. 302, No. 2, 302:539-544

10. Charved YL \& Boulange AQ, 2011, Mini Rivew, Role of adipose tissue renin-angiotensin system in metabolic and inflammatory diseases associated with obesity. international Society of Nephrology, Kidney International $79,162-16$

11. Benigni A, Cassis P, Remuzzi G, 2010. Angiotensin II revisited: new roles in inflammation, immunology and aging, EMBO Molecular Medicine Vol 2, 247-257

12. Mechanisms ${ }^{\mathrm{TM}}$ is a trademark of Core Health Services Inc., registered in the US and Canada., 2012

13. Vikrant S, Tiwan SC. Essential hypertension - pathogenesis \& pathophysiology, 2001. Journal Indian Academy of Clinical Medicine, 2(3): 140-161

14. Rahardjo P, 2015. Hubungan Hipertensi dengan Penyakit Ginjal. Indonesia Kidney Care Club, http://ikcc.or.id/healthtips/hubungan-hipertensi-denganpenyakit-ginjal/ .

15. Palm F, Nordquist L, 2011. Renal oxidative stress, oxygenation, and hypertension. Am J Physiol Regul Integr Comp Physiol 301: R1229$\mathrm{R} 1241$ 
16. Haase VH, 2013. Mechanisms of Hypoxia Responses in Renal Tissue. Science in Renal Medicine, J Am Soc Nephrol 24: 537-541
17. Hong NJ \& JL Garvin, 2015. Endogenous flow-induced nitric oxide reduces superoxidestimulated $\mathrm{Na} / \mathrm{H}$ exchange activity via $\mathrm{PKG}$ in thick ascending limbs.Am. J. Physiol. Renal Physiol. 308:F444-9 